\title{
Nursing awareness of oxygen therapy among nurses at selected district hospital in Nepal
}

\author{
Kalpana Katel ${ }^{(i)}$, Sunita Gurung ${ }^{(D)}$, Srijana Gautam ${ }^{(i)}$, Muna Bhattrai \\ Gandaki Medical College Teaching Hospital and Research Center, Pokhara, Nepal \\ $\varangle$ katelkalpana@gmail.com
}

\begin{abstract}
Relevance. Oxygen therapy is commonly used in the emergency and critical cases which is the first line treatment in many critical conditions. Oxygen therapy is a medical treatment prescribed mainly for hypoxic patients, which provides oxygen at higher concentrations than that found in atmosphere ( $>21 \%)$. Oxygen administering depends on the needs of the patients' conditions and in some cases medical treatment. The present study aims to assess the level of awareness on oxygen therapy among nurses and examine the association between level of knowledge, attitude and selected socio-demographic variables. Materials and Methods. A quantitative descriptive cross-sectional study design was used. A non-probability purposive sampling technique was used to select 125 samples. The data were collected for 6 weeks using a semi-structured self-administered questionnaire. Descriptive statistics (frequency, percentage, mean, standard deviation) was used for quantitative data analysis and inferential statistics (chi-square) were used to find out the association between level of knowledge, attitude and selected socio-demographic characteristics of the respondents. Results and Discussion. The study revealed that $74.4 \%$ of the nurses had unsatisfactory level of knowledge, 20\% had average knowledge and 5.6\% had satisfactory level of knowledge regarding oxygen therapy. A significant association was found between the knowledge level and age, educational status and experience of the respondents $(p=0.001$, $0.000,0.016)$. Conclusion. The study concluded that the level of knowledge among nurses regarding oxygen therapy has lower than expected and is unsatisfactory. The results of the study can provide a framework for the healthcare policymakers to develop and implement educational programs on oxygen therapy for nurses in hospital setting.
\end{abstract}

Keywords: oxygen therapy, hypoxia, nurses, knowledge

Author contributions. The authors declare an equal contribution to the participations of the article.

Acknowledgement. We would like to thank all the study subjects who kindly cooperate in providing required information even during the pandemic.

Conflicts of interest statement. The authors declare no conflict of interest.

Received 27.05.2021. Accepted 11.06.2021.

(C) Katel K., Gurung S., Gautam S., Bhattrai M., 2021

This work is licensed under a Creative Commons Attribution 4.0 International License https://creativecommons.org/licenses/by/4.0/ 
For citation: Katel K, Gurung S, Gautam S, Bhattrai M. Nursing Awareness of Oxygen Therapy among Nurses at selected District Hospital in Nepal. RUDN Journal of Medicine. 2021;25(3):202-208. doi: 10.22363/2313-0245-2021-25-3-202-208

Oxygen therapy (OT) is a medical treatment prescribed mainly for hypoxic patients, which provides oxygen at higher concentrations that found in atmosphere ( $>21 \%$ ) [1]. It is listed as a core item on the World Health Organizations (WHO) model of essential medicines, which is a list of the most effective and safe [2]. OT is vital to sustain human life it is one of the most widely prescribed for patients with different health conditions. Oxygen therapy is commonly used in the emergency and critical cases which is the first line treatment in many critical conditions. Oxygen administering depends on the needs of the patients conditions and in some cases medical team also advises. If oxygen therapy is given inappropriately, it could be fatal. Hence, patients must receive OT in an appropriate, safe, and comfortable way [3]. Although oxygen therapy is lifesaving, it may be associated with deleterious effects when administered for prolonged periods at high concentrations. In the human body, oxygen is making up $65 \%$ of body mass. Oxygen plays a very essential role in the body; as it allows humans to burn food, releasing energy. Every cell in the human body needs oxygen to survive [4]. Individuals' health status, activity level, and hydration are factors affected by how much human being needs for oxygen. Without adequate oxygen, health problems are definitely occurring. Oxygen deprivation in human body doesn't occur suddenly, it could take long time to occur, occurring over months or years. The reasons for oxygen deprivation are varied, that might result from individual's heath factors or environmental factors. The health effects of oxygen deprivation can be severe, it's even linked to tumor growth [5].

Oxygen therapy, when performed with appropriate dosage, is useful, however, it has significant adverse effects in addition to its therapeutic characteristic when performed inappropriately. Among these adverse effects are hypoventilation, atelectasis, pulmonary oxygen toxicity, retrolental fibroplasia, irritation, pain and infection [6-7].
Nurses are the medical team who are directly dealing with patients life for 24 hours, OT is commonly used in the hospital so the knowledge on OT is essential for the nurses.

Oxygen supplementation is a lifesaving treatment in emergency conditions and is commonly used as a therapeutic agent in emergency and ICU departments. Many patients cannot survive without additional oxygen treatment [8]. Oxygen therapy is prescribed in patients to reduce the respiratory work [9]. Even if oxygen therapy is lifesaving agent, it can also cause adverse effects when given for long periods at high concentration. According to Browne \& Crocker; Oxygen should be administered to achieve a target saturation of $94-98 \%$ for most critically ill patients or 88-92 \% for those at risk of respiratory insufficiency of hypercapnia [10].

Decisions of nurses in oxygen therapy are very important and may impact patient outcomes. Critical care nurses must be equipped by knowledge, good attitude in the oxygen administration practices of critical ill patients [11]. In developing countries, the staff is not well trained in caring for critically ill patients, leading to a lack of knowledge of critical care principles and that cause a barrier to quality care [12].

A study among nurses' knowledge, attitude and practice about oxygen therapy in Orotta national hospital showed that the mean percentage score on knowledge, attitude and practice were $40 \%, 60 \%$ and $60 \%$ respectively. Knowledge, attitude and practice on oxygen therapy was good in $43.3 \%$ for knowledge; $63.3 \%$ for attitude; $45 \%$ for practice respectively. It was found out that poor knowledge, attitude and practice on oxygen therapy were attributed due to lack of training, availability of oxygen therapy guidelines, and adequate supply of oxygen and delivery devices. This study showed that there was a gap in knowledge, attitude and practice among the respondents [13].

Based on the evidence from earlier studies, nurses' knowledge and attitude regarding oxygen therapy are shown poor. In the context of developing countries 
like Nepal few studies has been conducted till now. Taking into consideration of these issues, this study is aimed to assess knowledge and attitude on oxygen administration among nurses.

\section{Materials and methods}

A quantitative descriptive cross-sectional study design was used. A non-probability purposive sampling technique was used to select 125 samples. The data were collected for 6 weeks using a semi-structured self-administered questionnaire. Descriptive statistics (frequency, percentage, mean, standard deviation) was used for quantitative data analysis and inferential statistics (chi-square) were used to find out the association between level of knowledge, attitude and selected socio-demographic characteristics of the respondents.

The study has been approved by Institutional Review Ethical Committee of Gandaki Medical College (GMC_-IRC) of Nepal. Written informed consent has also been obtained from the research participants.

\section{Results and its discussion}

The response of the study was only $88 \%$ because of unviability of respondent during COVID19. More than half (57.6 \%) of the respondents were aged 25 years and above, with a mean age of 26. More than half $(56.8 \%)$ of the respondent were PCL nursing. one third (63.2 \%) of the respondents had more than 2 years of experience. Half (52.8 \%) of respondents works in general wards. Majority (90\%) of the respondent did not get training regarding oxygen therapy.

\section{Level of knowledge regarding oxygen therapy}

Regarding the level of knowledge three forth $74.4 \%$ of the respondents had unsatisfactory level of knowledge on oxygen therapy. About $20 \%$ of respondent had average level of knowledge on oxygen therapy. Only $5.6 \%$ of respondent had satisfactory level of knowledge on oxygen therapy.
Table 1

Socio- demographic Characteristics of the Respondents $(\mathrm{N}=125)$

\begin{tabular}{|c|c|c|}
\hline Variables & Number & Percentage (\%) \\
\hline Age in years & & \\
Less than 25 years & 53 & 42.4 \\
25-40 & 72 & 57.6 \\
Median=25, Min=19, Max=39 & & \\
Education & & \\
PCL & 71 & 56.8 \\
Bachelor & 54 & 43.2 \\
Experience & & \\
0-2 years & 46 & 36.8 \\
More than 2 years & 79 & 63.2 \\
Working unit & & \\
Critical ward & 59 & 47.2 \\
General ward & 66 & 52.8 \\
Training & & \\
No & 120 & 96.0 \\
Yes & 5 & 4.0 \\
\hline
\end{tabular}

Table 2

\begin{tabular}{|c|c|c|}
\multicolumn{2}{|c}{ Level of knowledge regarding oxygen therapy } \\
\hline Level & Number & Percentage \\
\hline $\left.\begin{array}{c}\text { Unsatisfactory } \\
\text { Less than 60\% } \\
\text { Average } \\
\begin{array}{c}60-75 \% \\
\text { Satisfactory } \\
\text { More than 75\% }\end{array}\end{array}\right)$ 93 & 74.4 \\
\hline
\end{tabular}

Regarding the level of attitude almost all $95.2 \%$ of respondents had positive attitude towards oxygen therapy. Only $4.8 \%$ of respondents had negative attitude towards oxygen therapy.

Table 3

Level of attitude towards oxygen therapy

\begin{tabular}{|c|c|c|}
\hline Level & Number & Percentage \\
\hline Positive & 119 & 95.2 \\
Negative & 6 & 4.8 \\
\hline
\end{tabular}

Factors affecting the level of knowledge

The factors that may contribute to the knowledge level of respondents were analyzed. Chi-square test revealed a significant association between the level of 
knowledge and age $\left(\chi^{2}=9.034, \mathrm{p}=0.011\right)$, Education $\left(x^{2}=29.724, \mathrm{p}=0.000\right)$, Experience $\left(x^{2}=8.299\right.$, $\mathrm{p}=0.016)$. However working unit and training had no significant association with the level of knowledge of respondents.

Table 4

Association between level of knowledge and sociodemographic characteristics

\begin{tabular}{|c|c|c|c|c|c|}
\hline \multirow{2}{*}{ Characteristics } & \multicolumn{3}{|c|}{ Knowledge Level } & \multirow{2}{*}{$\chi^{2}$} & \multirow{2}{*}{$p$-value } \\
\hline & Unsatisfactory n (\%) & Average $\mathrm{n}(\%)$ & Satisfactory n (\%) & & \\
\hline $\begin{array}{c}\text { Age in years } \\
\text { Less than } 25 \text { years } \\
25-40\end{array}$ & $\begin{array}{l}39 \\
54\end{array}$ & $\begin{array}{c}9 \\
15\end{array}$ & $\begin{array}{l}5 \\
3\end{array}$ & 9.034 & $0.011^{\star}$ \\
\hline $\begin{array}{l}\text { Education } \\
\text { PCL } \\
\text { Bachelor }\end{array}$ & $\begin{array}{l}66 \\
27\end{array}$ & $\begin{array}{c}4 \\
21\end{array}$ & $\begin{array}{l}1 \\
6\end{array}$ & 29.724 & $0.000^{\star}$ \\
\hline $\begin{array}{l}\text { Experience in years } \\
0-2 \text { years } \\
\text { More than } 2 \text { years }\end{array}$ & $\begin{array}{l}41 \\
52\end{array}$ & $\begin{array}{c}4 \\
21\end{array}$ & $\begin{array}{l}1 \\
6\end{array}$ & 8.299 & $0.016^{*}$ \\
\hline $\begin{array}{l}\text { Working unit } \\
\text { Critical ward } \\
\text { General ward }\end{array}$ & $\begin{array}{l}45 \\
48\end{array}$ & $\begin{array}{l}12 \\
13\end{array}$ & $\begin{array}{l}2 \\
5\end{array}$ & 1.034 & 0.596 \\
\hline $\begin{array}{l}\text { Training } \\
\text { No } \\
\text { Yes }\end{array}$ & $\begin{array}{c}89 \\
4\end{array}$ & $\begin{array}{c}24 \\
1\end{array}$ & $\begin{array}{l}7 \\
0\end{array}$ & 0.314 & 0.855 \\
\hline
\end{tabular}

Factors affecting the level of attitude

The factors that may contribute to the attitude level of respondents were also analyzed. Chi-square test revealed no association between the level of attitude with the sociodemographic variables.

The present study shows that majority of the respondents have unsatisfactory level of knowledge on oxygen therapy less than one third have average and only few respondents have satisfactory knowledge, whereas majority of respondents have positive attitude and only few respondents have negative attitude towards oxygen therapy.

The study findings are similar with the study conducted among north east Africa done by Fanuel et al [14] where poor or unsatisfactory knowledge on oxygen therapy. The study findings are also similar with the study done by Addis which revealed that nurses in hospital of Ethiopia do not have sufficient of knowledge about oxygen therapy [15]. The study findings are also in line with another study done in Turkey which revealed that the majority of respondents in this study have inadequate knowledge on oxygen therapy [16].

The current study shows that age, education and experience have significant association with education status. The study findings which are significant with age is similar with the study conducted by the Demirel H. in Turkey [16]. Education level is significant in our study which is similar to study conducted by V. Uwineza Didi in hospital of Rwanda [17]. Likewise, another significant in our study experience is similar to the study conducted by Demirel H. in hospital of Turkey [16].

The current study shows no association between levels of knowledge with working unit, training. In contrary study conducted by Demirel H. [16] showed there were significant associations between the level of knowledge on oxygen therapy and working unit $(\mathrm{P}=0.000)$. The similar study done by Ghebremichael F.G. also showed there were no significant association between level of knowledge on oxygen therapy and training $(\mathrm{P}=0.157)$ [14]. 
Association between level of attitude and socio-demographic characteristics

\begin{tabular}{|c|c|c|c|c|}
\hline \multirow[b]{2}{*}{ Characteristics } & \multicolumn{2}{|c|}{ Attitude Level } & \multirow[b]{2}{*}{$\chi^{2}$} & \multirow[b]{2}{*}{$p$-value } \\
\hline & $\begin{array}{c}\text { Positive } \\
\text { n (\%) }\end{array}$ & $\begin{array}{c}\text { Negative } \\
\mathrm{n}(\%)\end{array}$ & & \\
\hline $\begin{array}{c}\text { Age in years } \\
\text { Less than } 25 \text { years } \\
25-40 \\
\text { Education } \\
\text { PCL } \\
\text { Bachelor } \\
\text { Experience in years } \\
0-2 \text { years } \\
\text { More than } 2 \text { years } \\
\text { Working unit } \\
\text { Critical ward } \\
\text { General ward } \\
\\
\text { Training } \\
\text { No } \\
\text { Yes }\end{array}$ & $\begin{array}{l}50 \\
69 \\
68 \\
51\end{array}$ & $\begin{array}{l}3 \\
3\end{array}$ & $\begin{array}{r}2.358 \\
2.633\end{array}$ & 0.492 \\
\hline
\end{tabular}

The study regarding attitude shows there is no association between attitude towards oxygen therapy and selected variables.

\section{Limitation of the study}

The study was conducted in a single hospital and might not reflect the knowledge of all the nurses in general which might limit the generalizability of the findings of the study. Also as this study is a cross sectional study, chances of recall bias may be high.

\section{Conclusion}

The study revealed that the level of knowledge among nurses regarding oxygen therapy has lower than expected and their knowledge is particularly unsatisfactory in terms of oxygen therapy. There was a gap in knowledge and attitude among the participants. Some of the possible factors were also identified which includes age, education level and experience.

The results of the study can provide a framework for the policymakers to develop and implement educational programs on oxygen therapy for nurses in hospital setting.

\section{References}

1. Victor K, Joshua O, Benditt, Robert A, Wise and Amir S. Oxygen Therapy in Chronic Obstructive Pulmonary Disease. Proceedings of the American Thoracic Society. 2008; 5(4):513—518.

2. World Health Organization (WHO). Essential medicines and health products: WHO Model Lists of Essential Medicines. Geneva: WHO. 2016; 33-47. (Accessed March 03, 2021)

3. Adipa FE, Aziato I and Zakariah AN. Qualitative exploration of nurses' perspectives on clinical oxygen administration in Ghana. International Journal of Africa Nursing Sciences. 2015; 2:42-46.

4. Kelly CA and Michelle M. How do healthcare professional perceive oxygen therapy. A critical interpretative synthesis of the literature. 2015; Available at: http://journals.sagepub.com/doi/ abs/10.1177/1479972314562408.

5. Sobek, J. (2017). What occurs when Oxygen saturation levels are high? Available at: Healthfully, http://healthfully.com/occursoxygen- saturation-levels-high- 8396737.html. 27 July 2017

6. Burton MA, Ludwig LJ. Fundamentals of nursing care: concepts, connections \& skills. FA Davis; 2014 Oct 10.

7. Pasalioglu KB, Kaya H. Catheter indwell time and phlebitis development during peripheral intravenous catheter administration. Pakistan journal of medical sciences. 2014 Jul;30(4):725.

8. Alberta Health Services. Oxygen Therapy for Acute Adult Inpatients. Allied Health Services. 2016;1-60.

9. Lemma $\mathrm{G}$ and A Weldetsadik. Assessment of nurses knowledge, attitude and practice about oxygen therapyatemergency department. 2015; 28-34.

10. Browne B and Crocker C. Guidelines for the Administration of oxygen in adults. Nottingham University Hospital. 2013; 11-18. 
11. Eastwood GM, Reade MC, Peck L, Baldwin I, Considine J, Bellomo R. Critical care nurses’ opinion and self-reported practice of oxygen therapy: A survey. Australian Critical Care. 2012; 25(1):23-30.

12. Baker T. Critical care in low-income countries. Tropical Medicine \& International Health. 2009;14(2)143-148.

13. Linto MT et al. Assessment of nurses' knowledge, attitude and practice about oxygen therapy in emergency and icu departments of orotta national referralhospital. International Journal of Medicine and Health Profession Research. 2019; 6(1):102-111.

14. Ghebremichael FG, Thomas LM, Yohannes A, Kesete KY, Wolday SJ, Ghebrewoldi FH, Mengstu HT, Kuriakose A. International Journal of Medicine and Health Profession Research.
15. Weldetsadik AS. Assessment of nurse's knowledge, attitude and practice about oxygen therapy at emergency departments of one federal and three regional hospitals in Addis Ababa, Ethiopia. 2015.

16. Demirel H, Erek Kazan E. Knowledge levels of nurses about oxygen therapy in Turkey. International Journal of Health Services Research and Policy. 2020; 5(1): 1-14

17. Uwineza Didi V. Knowledge, attitudes and practice among nurses toward oxygen administration to the critically ill patients at UTHK (Doctoral dissertation, University of Rwanda).

\title{
Осведомленность медсестер о кислородной терапии в отдельной районной больнице Непала
}

\author{
К. Кател ${ }^{\square}$, С. Гурунг ${ }^{\mathbb{D}}$, С. Гаутам ${ }^{\mathbb{D}}$, М. Бхаттарай \\ Больница и исследовательский центр медицинского колледжа Гандаки, г. Покхара, Неnал \\ $\checkmark$ katelkalpana@gmail.com
}

Аннотация. Актуальность. Кислородная терапия обычно используется в неотложных и критических случаях и является лечением первой линии во многих критических состояниях. Кислородная терапия — лечение, назначаемое в основном пациентам с гипоксией, при котором подается кислород в концентрации более высокой, чем в атмосфере (> 21 \%). Подача кислорода зависит от состояния пациента и, в некоторых случаях, от лечения. Настоящее исследование направлено на оценку уровня осведомленности медсестер о кислородной терапии и изучение связи между уровнем знаний и социально-демографическими данными. Материалы и методы. Был использован количественный описательный дизайн исследования. Для отбора 125 образцов использовалась невероятностная целенаправленная выборка. Данные были собраны в течение 6 недель с использованием анкеты для самостоятельного заполнения. Описательная статистика (частота, процент, среднее значение, стандартное отклонение) использовалась для количественного анализа данных, а статистические данные (хи-квадрат) использовались для выяснения связи между уровнем знаний, отношением и выбранными социально-демографическими характеристиками респондентов. Результаты и обсуждение. Исследование показало, что 74,4 \% медсестер имели неудовлетворительный уровень знаний, 20 \% имели средний уровень знаний и 5,6 \% имели удовлетворительный уровень знаний о кислородной терапии. Была обнаружена значимая связь между уровнем знаний и возрастом, образовательным статусом и опытом респондентов (р = 0,001, 0,000, 0,016). Выводы. В результате исследования установлено, что уровень знаний медсестер относительно кислородной терапии ниже, чем ожидалось, и является неудовлетворительным. Результаты исследования могут послужить основой для разработки и реализации образовательных программ по кислородной терапии для медсестер в больницах.

Ключевые слова: кислородная терапия, гипоксия, медсестры, образование

Вклад авторов. Авторы внесли равный вклад в подготовке рукописи.

Благодарности. Авторы благодарят всех участников исследования, которые любезно сотрудничали в предоставлении необходимой информации даже во время пандемии.

Информация о конфликте интересов. Авторы декларируют отсутствие конфликта интересов. 
Поступила 27. 05. 2021. Принята 11. 06. 2021.

Для цитирования: Katel K., Gurung S., Gautam S., Bhattrai M. Nursing Awareness of Oxygen Therapy among Nurses at selected District Hospital in Nepal // Вестник Российского университета дружбы народов. Серия: Медицина. 2021. T. 25. № 3. С. 202-208. doi: 10.22363/2313-0245-2021-25-3-202-208

Corresponding author: Katel Kaplana — Lecturer, College of Nursing, Gandaki Medical College Teaching Hospital and Research Center. 33700, Pokhara-27, Nayabazar Rd, Kaski, Nepal. E-mail: katelkalpana@gmail.com

Katel K. ORCID 0000-0002-1615-4261

Gurung S. ORCID 0000-0001-6981-8351

Gautam S. ORCID 0000-0001-6213-0968

Bhattrai M. ORCID 0000-0002-0117-4788

Ответственный за переписку: Кател К. — Больница и исследовательский центр медицинского колледжа Гандаки, Непал, 33700, г. Покхар, ул. Найабазар. E-mail: katelkalpana@gmail.com

Кател K. ORCID 0000-0002-1615-4261

Гурунг C. ORCID 0000-0001-6981-8351

Гаутам C. ORCID 0000-0001-6213-0968

Бхаттарай M. ORCID 0000-0002-0117-4788 